\title{
Prediction models for estimating foliar and fruit dry biomasses of five Savannah tree species in the West African Sahel
}

\author{
Mahamane LARWANOU ${ }^{1 *}$, Yonas YEMSHAW ${ }^{1}$ and Mahamane SAADOU ${ }^{2}$ \\ ${ }^{1}$ African Forest Forum (AFF) Clo World Agroforestry Center (ICRAF) United Nations Avenue \\ P.O.Box 30677 - 00100, Nairobi, Kenya; Tel: +254207224000 Ext 4624 ; Cell: +22796973442 OR \\ +254714997787; Website: www.afforum.org \\ ${ }^{2}$ Department of Biology, Faculty of Science University Abdou Moumouni de Niamey, BP 10662, Niamey, \\ Niger.Tel/Fax: +227 733072; e-mail: saadou_mahamane@yahoo.fr \\ *Corresponding author; E-mail: m.larwanou@cgiar.org
}

\begin{abstract}
The objective of the study was to develop models for estimation of leaf and fruit biomasses of Faidherbia albida Delile, Prosopis africana (Guill. Perrott. and Rich.) Taub, Piliostigma reticulatum (DC.) Hochst, Bauhinia rufescens Lam. and Ziziphus mauritiana Lam in the West African Sahel. Direct evaluation of leaf and fruit biomass through destructive method was used to estimate the biomasses of fruits and leaves. Diameter at breast height and crown diameter were candidate explanatory variables and both were significant $(p<0.01)$ estimators of biomass for all species except Faidherbia albida predicting leaf biomass $(p=0.33)$ and Prosopis africana predicting fruit biomass $\left(p=0.13\right.$ ). The model fit values for all models were $R^{2} \geq 0.80$ other than the foregoing two exceptions. The conclusion related to the objective was that the models are well suited to estimate leaf and fruit production of the five Savannah species in the parkland ecosystem of the African Sahel with the two exceptions.
\end{abstract}

(C) 2010 International Formulae Group. All rights reserved.

Keywords: Faidherbia albida, Prosopis africana, Piliostigma reticulatumt, Bauhinia rufescens and Ziziphus mauritiana, Sahel, Niger.

\section{INTRODUCTION}

In the Sahel region of West Africa, trees play an important role in the lives of human and animal populations. This role includes sustaining livelihoods through provision of food, shelter, medicinals, and feeds for animals. Trees also constitute tangible assets for resource poor people (Belem et al., 2007; Faye et al., 2010). It is for these reasons that trees are preserved and managed by local communities in their farm lands (Lykke, 1998; Boffa, 1999; IIED, 2003;
Larwanou and Saadou, 2005). Trees are selected and preserved on farm according to farmers' use based priorities. This has changed the species composition on the farm landscape (Bayala et al., 2002; Garrity et al., 2010; Larwanou and Saadou, 2011).

In the Sahel, because of the predominance of livestock husbandry, some trees like Faidherbia albida, Prosopis africana, Piliostigma reticulatum, Bauhinia rufscens and Ziziphus mauritiana are preserved because of the fodder they provide 
for animals through leaves and fruits especially during the long dry season. Most of the ruminants use the fodder from trees to supplement their diet in terms of protein, minerals and vitamins (Le Houerou, 1980) and livestock herders preserve tree fodder species in their farmers to collect leaves and fruits or pods to feed their animals (Sanon et al., 2007; Faye et al., 2010). Herders and even sedentary people who hold their cattle and other ruminants at home during the rainy season feed their animals with biomass from trees either through pruning or slashing. In most cases, pruning is the principal method of collecting animal feeds from trees (TerMikaelian and Korzukhin, 1997; Salis et al., 2006). The pods or fruits are harvested by shaking the tree or from the ground when they fall naturally. Zero grazing during the hot dry season and at the beginning of the rainy season was shown to reduce overgrazing, and increase manure production and grass regrowth in a study from southern Mali (Bosma et al., 1999).

The threat on some species like $P$. africana is important and could be linked to ecological, anthropogenic as well as economic factors. The open access over-exploitation of meager forest and tree resources, the disappearance of fallowing, overgrazing, as well as the general reduction of rain fall observed during the last decades can explain the significant loss of vegetation cover in various agroecological zones of the Sahel in general, and Niger in particular.

$F$. albida, $P$. africana and $P$. reticulatum which are predominant in parklands in Niger and Burkina are sources of fertilizer for the annual crops (Bayala et al., 2007; Larwanou et al., 2007). Farmers do prune $P$. africana, Parkia biglobosa and $P$. reticulatum during the rainy season to reduce excessive shading of the annual crops and also the leaves and other twigs are left in the field to decompose and improve soil fertility.

Where trees grow in combination with annual crops, like in the parkland systems, a number of complex interactions arise, resulting in both positive and negative effects on crop yield. Most studies of these interactions have been carried out in the Soudano-Sahelian agroecological zone that have relatively higher rainfall. However, the studies in the Sahelian zone (Boffa, 1999; Roupsard et al., 1999; Wezel, 2000; Wezel et al., 2000; Bayala et al., 2005) also found that scattered shrubs improved soil characteristics and millet yields. Studies of various agroforestry technologies, such as alley cropping, have also come to similar conclusions. In the areas where farmers have applied assisted natural regeneration (ANR), the ideal number of trees per unit area for optimal crop yield has been a matter of interest. Unfortunately, there is little scientific evidence so far to guide them.

Also, the fruits of many tree species like $Z$. mauritiana, $P$. africana and $P$. reticulatum are used for human consumption and complement the diet of low income families. For all these uses, it is fundamental to understand the quantity of leaf and fruit biomass produced by the various tree species preserved in the farms for better management. The purpose of this study is to provide useful tool for predicting biomass of five Sahelian tree species that are used for food, fodder, and soil fertility improvement. The findings could serve as guide for extension services as well as farmers, especially in the arid and semi-arid zones, to better manage trees in parkland systems.

\section{MATERIALS AND METHODS \\ Study site}

The study was conducted in Kollo district, situated $30 \mathrm{~km}$ South-West of Niamey $\left(2^{\circ} 18^{\prime} 28^{\prime \prime} \mathrm{E}, 13^{\circ} 15^{\prime} 00^{\prime \prime} \mathrm{N}\right)$, Niger. The mean annual precipitation at the station is around $500 \mathrm{~mm}$, with a long dry season from October to May. The mean annual temperature is approximately $28{ }^{\circ} \mathrm{C}$. The soil is sandy and low in Nitrogen.

The natural vegetation type in the area is dry savannah with trees, dominated by Guiera senegalensis, $P$. reticulatum, $B$. rufescens, $Z$. mauritiana, $F$. albida, $P$. africana, etc. (Larwanou et al., 2005). The 
mean tree density is estimated between $20-40$ trees/ha (Larwanou and Saadou, 2005). According to a survey conducted by INRAN in 1994, farmers in this study site ranked $F$. albida, $P$. africana, $P$. reticulatum, $B$. rufescens and $Z$. amuritiana as the preferred species because they provide green manure and fodder as well as their ease of availability. These tree species are scattered in farmed fields and are given due attention by farmers when preparing for crop production.

The local population practiced both farming and livestock husbandry in the parkland system. In this district, there are virtually no natural forests and both economic activities are carried out in farmed lands.

\section{Tree species characteristics}

Faidherbia albida (syn. Acacia albida Delile) is a species of Faidherbia native to Africa and the Middle East, formerly widely included in the genus Acacia. It is a thorny tree growing up to $6-30 \mathrm{~m}$ tall and $2 \mathrm{~m}$ in trunk diameter and grows in areas with 250$600 \mathrm{~mm} /$ year of rain (http://www.fao.org/ docrep/006/Q2190E/Q2190E10.htm). The species occurs as scattered individuals or in groves in a wide range of habitats, ranging from the vegetation on alluvial soils fringing perennial or seasonal water-courses to open Savannah wood and cultivated lands. It prefers deep sandy soils where the water-table is accessible to the tree roots and it is therefore independent of local rain once established. This tree is particularly valued in agricultural areas on account of its unusual habit of retaining its leaves during the hot weather and dropping them during the rains (FAO, 1974a). The pods and leaves are very good fodder and the pods, prolific crops of which are produced annually, can be stored. The pod and leaf fall, together with the dung and urine of cattle that seek the shade of trees in hot weather, improve the nutrient status and organic content on the soil near established trees, so that yields of sorghum and other agricultural crops cultivated during the rains are considerably increased. The cattlecarrying capacity of the land is also improved where this tree is present, because of the excellent leaf and pod fodder produced at a time when grass is scarce. It is therefore an important tree in village economy and, in some regions, is declared a protected tree. It is among the most preferred species by farmers in the Sahel because of its soil fertilizing and fodder providing roles.

Prosopis africana (Guill. Perrott. and Rich.) Taub. has been considered as important to farming and pastoralist communities in the Sahel region of West Africa because it provides several essential products and services. The fruit is fed to animals, while the seeds are fermented to make a protein-rich condiment. The wood is dense and resistant to termites and fungi (Nygård and Elving 2000; Gérardin et al., 2004) and is valued for firewood (Pasiecznik et al., 2004; Sotelo et al., 2009). The tree has been reported to increase soil fertility and fix nitrogen (Halliday 1984; Larwanou, 1994). The leaves and pods of this species are used for fodder and highly appreciated by big ruminants (Weber et al., 2008). It is among the most preferred trees in the parklands in the Sahel.

Piliostigma reticulatum (DC.) Hochst is a tree frequently preserved in cultivated field and fallow lands, evergreen shrub or small tree with a twisted bole to $9 \mathrm{~m}$ high, with a bushy spherical canopy (Aubreville, 1950). It is found on various kinds of soils from sandy to clay and lateritic and throughout the Sahelian and Sudanian ecozones from Mauritania to Sudan, extending to East Africa, up to 2,000 m elevation (Le Houerou, 1980). The leaves are pounded while pods are boiled to make local drinks. The bark is used for cordage while twigs and leaves are consumed by cattle, sheep and goats, the latter prefer pods (Burkill, 1995).

Bauhinia rufescens Lam. is deciduous in drier areas and is an evergreen in wetter areas. It is often found in dry Savannah, especially near stream banks. It is found in the entire Sahel and adjacent Sudan zone, from Senegal and Mauritania, across North Ghana and Niger to central Sudan and Ethiopia. It 
can thrive in the mean annual rainfall range from 400-1000 $\mathrm{mm}$ and found on poor, arid, sandy, stony soils, as well as on deep clays (Orwa et al., 2009). The green and dried fruit and the leaves and shoots are valuable forage, favoured by many species of wild and domestic animals, which may cause the extinction of $B$. rufescens in regions overstocked with livestock. In Sudan, the pods are said to be the most valuable forage for camels. Planting B. rufescens in dunes can help stabilize and control them. B. rufescens provides a good, impenetrable, browseresistant live fence; useful for protecting gardens, fields and compounds.

Ziziphus mauritiana Lam. is a spiny, evergreen shrub or small tree up to $15 \mathrm{~m}$ high, with trunk $40 \mathrm{~cm}$ or more in diameter; spreading crown; stipular spines and many drooping branches. Fruit quality is best under hot, sunny and dry conditions, but there should be a rainy season to support extension growth and flowering, ideally leaving enough residual soil moisture to carry the fruit to maturity (Orwa et al., 2009). The tree is remarkable in its ability to tolerate waterlogging as well as drought and can grow where annual rainfall ranges from 300 to $500 \mathrm{~mm}$. Commercial cultivation usually extends up to $1000 \mathrm{~m}$ and beyond this elevation, trees do not perform well, and cultivation becomes less economical. Z mauritiana is a fast-growing species. Under favourable conditions, height increment on loose soil is $75 \mathrm{~cm}$ in 1 year and $1.2 \mathrm{~m}$ in 2 years; growth is stragglier by the 3rd season, when under similar growth conditions plants are thick and bushy, up to $1.5 \mathrm{~m}$ high. Fruit is eaten fresh or dried and can be made into a floury meal, butter, or a cheese-like paste, used as a condiment. Also used for candy making and pickling, the fruit is a good source of carotene, vitamins $\mathrm{A}$ and $\mathrm{C}$, and fatty oils. A refreshing drink is prepared by macerating fruits in water. In Indonesia, young leaves are cooked as a vegetable. In parts of India and North Africa, the leaves of Z. mauritiana are used as nutritious fodder for sheep and goats.

\section{Experimental design and data collection}

In the study area, 3 plots of $100 \mathrm{~m} \mathrm{X}$ $100 \mathrm{~m}$ ( $1 \mathrm{ha}$ ) were laid randomly in the farms and tree inventory was carried out. The following parameters were measured on each mature tree of a given species: total height (TH), the diameter at breast height (DBH) (1.3 $\mathrm{m}$ above ground), the mean crown diameter (MCD). A mature tree in this study is any tree of a given species that bore fruits at the time of the study and had reasonable height and diameter. After the inventory, five main tree and shrub species were identified as follows: $P$. africana, $F$. albida, $P$. reticulatum, $B$. rufscens and Z. mauritiana. The data for these species were assorted and diameter at $1.3 \mathrm{~m}$ and corresponding crown diameter were determined and classified accordingly. Each tree of a given species was given a number and based on that, the diameter classes were determined for each species. Three diameter classes and their corresponding crown diameter classes were used for each species. All trees having diameters that fell in the range of a given class were sorted together and used to obtain the mean value (Table 1).

This mean value was used to identify the tree that had more or less this dimension. In each diameter class and its corresponding crown diameter, 9 trees were randomly picked and constituted sample trees for each species on which the leaf and tree biomass data were collected (Table 1).

To evaluate the leaf and fruit biomasses, a destructive method was used with the permission of the land owner. In order to reduce the loss and mutilation of the trees, 1/3 of the crown of a given sample tree was cut. The leaves and the fruits for each tree were meticulously removed separately by laborers and weighed immediately. Five per cent of the weight of both leaves and fruits were taken to the laboratory for sun drying for one week and oven dry for 48 hours at 70 degrees centigrade to obtain constant weight. This constant weight is then extrapolated to the whole tree of a given species. The mean weight from 9 trees were then calculated for both leaf and fruit biomasses. 


\section{Data analysis}

The Statistical Package for Social Sciences (SPSS) software was used to determine the mean values of $\mathrm{DBH}$ and MCD, as well as the weight of leaves and fruits. Based on mean values of DBH and MCD the measured samples trees were classified into three size classes. For each species, the size classes were regressed against weight of leaves and fruits. Relationships among tree parameters were investigated using correlation and regression analysis. A simple linear regression model was used to obtain the regression equation $(\mathrm{y}=\mathrm{ax}+\mathrm{b}$; with $\mathrm{a}=$ intercept and $b=$ coefficient), so that for each species:

Leaf biomass $(\mathrm{KG})=\mathrm{a}+\mathrm{b}$ ( size class $)$,

Fruit biomass $(\mathrm{KG})=\mathrm{a}+\mathrm{b}($ size class $)$,

Regression parameters for a straight line model $(Y=a+b x)$ are calculated by the least squares method (minimization of the sum of squares of deviations from a straight line). This differentiates to the following formulae for the slope (b) and the Y intercept (a) of the line:

$$
\begin{aligned}
& b=\frac{\sum_{i=1}^{n}\left(x_{i}-\bar{x}\right)\left(Y_{i}-\bar{Y}\right)}{\sum_{i=1}^{n}\left(x_{i}-\bar{x}\right)^{2}} \\
& a=\bar{Y}-b \bar{x}
\end{aligned}
$$

The data was tested to satisfy the regression assumption that leaf and fruit weight is linearly related to size class, so no transformation was necessary. Residuals followed normal distribution and had uniform variance, as well.

The coefficient of determination $\left(\mathrm{R}^{2}\right)$ and the correlation coefficient between species and tree size classes, and, the coefficient of correlation (R) among tree parameters within each species were determined. For this analysis, tree size (DBH and MCD) was considered as fixed factor for a given species and the leaf and fruit biomasses as dependent variables.

\section{RESULTS \\ Leaf and fruit biomasses}

The leaf biomass increases with tree size for $P$. africana, $P$. reticulatum and $Z$. mauritiana from $67.52 \pm 44.85-100.48 \pm$ $37.84,12.4 \pm 3.6-23.32 \pm 15.27$ and $22.45 \pm$ $13.4-33.42 \pm 14.22$ respectively. For both F.albida and $B$. rufescens, the mean leaf biomass for class 2 was slightly lower than in class 1 (Table 2).

With regards to fruit biomass, except for $P$. africana, there is an increase with tree size for the other four species. The trees from class 1 in $P$. africana produced more fruit than the others from classes 1 and 2 with $92.38 \pm$ $64.78,71.52 \pm 69.75$ and $84.67 \pm 67.3$ respectively (Table 2 ).

The differences in both leaf and fruit biomasses between species are due to the morphological feature of the species. The species characteristics revealed that DBH and MCD were different form one species to another and based on that the following descending order was obtained: $F$. albida $>P$. africana $>$ P. reticulatum $>$ B. rufescens $>Z$. mauritiana (Table 1).

\section{Relationships between species and tree size for leaf and fruit biomass production}

$P$. africana: the regression equations between tree size and the tree products of $P$. africana indicated that the relationship between tree size vs leaf biomass and tree size vs fruit biomass accounted for 88 and $13 \%$ respectively (Table 3 ). For this species, the relationship between tree size and fruit production is very low as reflected in the mean fruit production.

F. albida: the relationship between tree size and leaf and fruit biomass indicates 33 and $99 \%$ respectively revealing a low correlation between the size of the tree and the corresponding leaf production (Table 3 ).

$P$. reticulatum: Coefficients of determination of 87 and $80 \%$ were obtained respectively for leaf and fruit biomasses indicating a strong relationship between the 
size of the tree and these parameters for this species (Table 3).

B. rufescens: 86 and $85 \%$ of coefficients of determination were obtained between tree size and leaf and biomass production in this species.

Z. mauritiana: for this species, there are high coefficients of determination between tree size and leaf and fruit production of 99 and $81 \%$ respectively.

\section{Relationship among tree parameters within a species}

In terms of tree parameter within a given species, Table 4 below indicates the followings:

$P$. africana: there was a highly significant correlation $(\mathrm{p}<0.01)$ between leaf biomass and tree size $(r=0.94)$ and a negative correlation between tree size vs fruit biomass indicating that fruit production is not related to the size of the tree. Also, there was weak correlation between leaf production and fruit in this species ( $\mathrm{r}=-0.03$ ) (Table 4).
F. albida: significant $(\mathrm{p}<0.05)$ and highly significant $(\mathrm{p}<0.01)$ correlations were obtained between tree size vs leaf and tree size vs fruit production in this species with $r=$ 0.57 and $r=99$ respectively. The correlation between leaf and fruit was significant ( $p<0.05$ and $r=54)$, revealing that for this species, leaf bearing is fundamental for fruit production.

$P$. reticulatum: the correlations between leaf vs tree size and fruit vs tree size are highly significant $(\mathrm{p}<0.01)$ and significant between leaf and fruit production.

$B$. rufescens: this follows the same trend like $P$. reticulatum. This result suggests that the 2 species behave the same way physiologically and could be expected because they belong to the same family.

Z. mauritiana: strong correlations ( $\mathrm{p}<$ 0.01 ) existed between all the parameters for this species denoting that leaf and fruit production follows the tree size and that fruit production depends on the quantity of leaf that bears a particular tree species.

Table 1: Diameter classes for the 5 species.

\begin{tabular}{llcc}
\hline Species & Classes & Diameter BH (cm) & $\begin{array}{c}\text { Mean crown } \\
\text { diameter }(\mathbf{m})\end{array}$ \\
\hline Faidherbia albida & 1 & $25-39$ & $14-17$ \\
& 2 & $40-59$ & $18-20$ \\
& 3 & $60>$ & $20>$ \\
\hline Prosopis africana & 1 & $30-40$ & $8-11$ \\
& 2 & $41-59$ & $12-17$ \\
& 3 & $60>$ & $18>$ \\
\hline Piliostigma reticulatum & 1 & $12-19$ & $8-12$ \\
& 2 & $20-30$ & $13-17$ \\
& 3 & $31>$ & $18>$ \\
\hline Bauhinia rufscens & 1 & $10-15$ & $3-4$ \\
& 2 & $16-20$ & $5 .-6$ \\
& 3 & $20>$ & $7>$ \\
\hline Ziziphus mauritiana & 1 & $9-12$ & $3-4$ \\
& 2 & $13-20$ & $4-5$ \\
& 3 & $21>$ & $5>$ \\
\hline
\end{tabular}


M. LARWANOU et al. / Int. J. Biol. Chem. Sci. 4(6): 2245-2256, 2010

Table 2: Mean leaf and fruit biomasses for the species according to tree size class.

\begin{tabular}{llcc}
\hline Species & Tree size class* & Leaf biomass (kg) & Fruit biomass (kg) \\
\hline Faidherbia albida & 1 & $46.89 \pm 23.17$ & $52.6 \pm 41.9$ \\
& 2 & $34.99 \pm 22.15$ & $89.2 \pm 21.4$ \\
& 3 & $62.86 \pm 46.16$ & $122.03 \pm 20.65$ \\
\hline Prosopis africana & 1 & $67.52 \pm 44.85$ & $92.38 \pm 64.78$ \\
& 2 & $73.61 \pm 29.01$ & $71.52 \pm 69.75$ \\
& 3 & $100.48 \pm 37.84$ & $84.67 \pm 67.3$ \\
\hline Piliostigma reticulatum & 1 & $22.45 \pm 13.4$ & $13.18 \pm 15.42$ \\
& 2 & $24.19 \pm 8.23$ & $21.9 \pm 13.35$ \\
\hline Bauhinia rufescens & 3 & $33.42 \pm 14.22$ & $22.53 \pm 14.29$ \\
\hline Ziziphus mauritiana & 1 & $23.1 \pm 16.9$ & $12.3 \pm 11.1$ \\
& 2 & $22.1 \pm 19.1$ & $19.05 \pm 11.1$ \\
& 3 & $32.12 \pm 16.2$ & $20.13 \pm 10.65$ \\
\hline
\end{tabular}

* Diameter at $1.3 \mathrm{~m}$ and its corresponding crown diameter 
Table 3: Simple regression equations and coefficients of determination between species and tree size classes for leaf and fruit biomass production.

\begin{tabular}{lcccc}
\hline Species & \multicolumn{2}{c}{ Leaf biomass } & \multicolumn{2}{c}{ Fruit biomass } \\
\cline { 2 - 5 } & Equation & $\begin{array}{c}\text { Coefficient of } \\
\text { determination }\left(\mathbf{R}^{\mathbf{2}}\right)\end{array}$ & Equation & $\begin{array}{c}\text { Coefficient of } \\
\text { determination }\left(\mathbf{R}^{\mathbf{2}}\right)\end{array}$ \\
\hline Faidherbia albida & $\mathrm{y}=7.985 \mathrm{x}+32.277$ & 0.33 & $\mathrm{y}=34.715 \mathrm{x}+18.513$ & 0.99 \\
Prosopis africana & $\mathrm{y}=16.48 \mathrm{x}+47.577$ & 0.88 & $\mathrm{y}=-3.855 \mathrm{x}+90.567$ & 0.13 \\
Piliostigma reticulatum & $\mathrm{y}=5.485 \mathrm{x}+15.717$ & 0.87 & $\mathrm{y}=4.675 \mathrm{x}+9.8533$ & 0.80 \\
Bauhinia rufescens & $\mathrm{y}=7.61 \mathrm{x}+7.4867$ & 0.86 & $\mathrm{y}=3.915 \mathrm{x}+9.33$ & 0.85 \\
Ziziphus mauritiana & $\mathrm{y}=5.46 \mathrm{x}+6.6167$ & 0.99 & $\mathrm{y}=6.265 \mathrm{x}+4.58$ & 0.81 \\
\hline
\end{tabular}

Table 4: Correlation relationships among tree parameters within each species.

\begin{tabular}{lccccc}
\hline Regression relationship & \multicolumn{4}{c}{ Correlation coefficients (r) for the different species } \\
\cline { 2 - 6 } & $\begin{array}{c}\text { Faidherbia } \\
\text { albida }\end{array}$ & $\begin{array}{c}\text { Prosopis } \\
\text { africana }\end{array}$ & $\begin{array}{c}\text { Piliostigma } \\
\text { reticulatum }\end{array}$ & $\begin{array}{c}\text { Bauhinia } \\
\text { rufescens }\end{array}$ & $\begin{array}{c}\text { Ziziphus } \\
\text { mauritiana }\end{array}$ \\
\hline Leaf biomass Vs Tree size class & $0.57^{*}$ & $0.94 * *$ & $0.93^{* *}$ & $0.93^{* *}$ & $0.99^{* *}$ \\
Fruit biomass Vs Tree size class & $0.99^{* *}$ & -0.37 & $0.89^{* *}$ & $0.92^{* *}$ & $0.90^{* *}$ \\
Leaf Vs Fruit & $0.54^{*}$ & -0.03 & $0.67^{*}$ & $0.71^{*}$ & $0.85^{* *}$ \\
\hline **Significant at the 1\% level; *Significant at the 5\% level & & &
\end{tabular}




\section{DISCUSSION}

The leaf and fruit biomass production for tree species in the parklands of the Sahel region are determined by a number of factors including the soil type, rainfall distribution and intensity, the intrinsic characters of the species as well as the management or human intervention. The method used in most cases for assessing leaf and fruit biomasses is usually destructive method, but indirect methods using regression equations based on more easily measured variables of the trees are frequently utilized for predicting biomasses. These approaches are widely used in forestry, either for the estimation of aboveground biomass (wood, branches, leaves) (Ter-Mikaelian and Korzukhin, 1997; Salis et al., 2006), or to assess the available browse for wildlife or domestic animals (Paton et al., 2002; Sard et al., 2005). The method used for this study in estimating the leaf and fruit biomasses was also used by some authors. In the Sahelian area single regression models for a few browse species have been developed (Bille, 1980; Cisse, 1980). Regression models and correlation can help established the relationships between tree parameters and also predict what could be obtained in a given forest or parkland system. The measurement carried out, especially for estimating the crown diameter is very easy in a Sahelian environment because of the open crown in the farmed field. Some other methods have been reported to be useful in the arid zone especially the canopy area and use of trunk diameter at breast height and height (Breman and Kessler, 1995).

The results obtained on these species are in accordance with those obtained by Savadogo and Elfving (2007) in a study that examined the possibility of using groundbased photographs to estimate browse production of Acacia dudgeoni and Balanites aegyptiaca in Burkina Faso. The results from the regression analysis indicated that all models were significant (all $\mathrm{p}$ values $<0.05$ ) for the two species but the predictive power was low for Acacia $\left(\mathrm{r}^{2}<0.50\right)$ compared to Balanites $\left(\mathrm{r}^{2}>0.75\right)$. Cisse (1980) in a study of the browse production of some trees of the Sahel and the relationships between maximum foliage biomass and various physical parameters, obtained highly significant correlations between biomass and circumference of the trunk for $F$. albida and Z. mauritiana with $r=0.98$ for both species. This result is similar to what it is obtained for $Z$. mauritiana with $\mathrm{r}=0.99$ but different for $F$. albida with $\mathrm{r}=0.57$. For the leaf biomass, the results were slightly different from those obtained in this study. For $F$. albida, Cisse (1980) obtained for the same class of diameter 44.6, 54.8 and 67.2 against $46.89 \pm 23.17$, $34.99 \pm 22.15$ and $62.86 \pm 46.16 \mathrm{~kg}$ for classes 1,2 and 3 respectively. For $Z$. mauritiana, the results obtained in this study are higher in terms of leaf biomass.

Some authors obtained different results in different ecological conditions. For instance, Dunham (1990) in a study to evaluate the fruit production by $F$. albida trees in Zambezi riverine woodlands estimated that a tree could produce between $5.4 \mathrm{~kg}$ to 290.1 $\mathrm{kg}$ depending on the year. This production is influenced by a series of factors among which insect and animal attacks. Predicting biomass and fruit production of Sahelian tree species is influenced by many other factors in addition to these already determined by various authors like the influence of human activities and climatic factors.

\section{Conclusion}

The determination of foliar and fruit biomasses of tree species in the Sahel is an important opportunity to provide this highly needed information to various users of parkland systems. The beneficiaries from this type of information are the extension agents to advise the farmers for managing their trees in the farm, scientists and farmers themselves. The models developed are very simple to be used by all actors. This study could be a good management tool that will help better exploitation of tree resources in farmed fields. It can assist in extrapolating the mean leaf and fruit production in a given parkland for better exploitation of the tree resource in similar 
agro-ecological conditions. Considering the diversity of tree species in different agroecological zones in the Sahel, research of this nature have to be undertaken in order to provide information for better management of trees by local users.

\section{ACKNOWLEDGEMENTS}

The authors wish to acknowledge the support of the Swiss Agency for Development and Cooperation (SDC) for funding this study.

\section{REFERENCES}

Achard F, Koniecka M, Montagne P, Banoin, M. 1996. Ressources ligneuses des jachères du sud-ouest du Niger. In Actes de l'atelier, la jachère lieu de production, tenue à Bobodioulasso du 2 au 4 octobre 1996, Projet 7 ACP. RPR. 269, Amélioration et gestion de la jachère en Afrique de l'ouest; 43 - 48.

Aubréville A. 1950. Flore forestière SoudanoGuinéenne, AOF, Cameroun, AEF. Soc. Ed. Géogr. Marit. \& Colon: Paris; $523 \mathrm{pp}$.

Bayala J, Mando A, Teklehaimanot Z, Ouedraogo SJ. 2005. Nutrient release from decomposing leaf mulches of karité (Vitellaria paradoxa) and néré (Parkia biglobosa) under semi-arid conditions in Burkina Faso, West Africa. Soil Biology and Biochemistry, 37(3): 533-539.

Bille JC. 1980. Measuring the primary palatable production of browse plants. In The Current State of Knowledge. Le Houerou HN (Ed), Browse in Africa. ILCA: Addis Ababa; 185-196.

Boffa J-M. 1999. Agroforestry Parklands of Sub-Saharan Africa [published in French as Les Parcs Agroforestiers en Afrique Subsaharienne]. Rome: FAO Conservation Guide; 34. 230 pp. [258 pp. in French].

Bosma RH, Bos M, Kante S, Kebe D, Quak W. 1999. The promising impact of ley introduction and herd expansion on soil organic matter content in southern Mali. Agricultural Systems, 62(1): 1-15.
Breman H, Kessler, JJ. 1995. Le rôle des ligneux dans les agro-écosystèmes des régions semi-arides (avec un accent particulier sur les pays sahéliens). ABDLO, Wageningen.

Burkill HM. 1995. The useful plants of West Tropical Africa. vol. 3, 857 pp. Caesalpinioideae, pp. 50-177 ; Mimosoideae, pp. 177-267 ; Papilionoideae, pp. 267-483. Royal Botanic Gardens, Kew.

Cisse MI. 1980. The browse production of some trees of the Sahel: relationships between maximum foliage biomass and various physical parameters. In: Le Houerou HN (Ed), Browse in Africa. The Current State of Knowledge. ILCA: Addis Ababa; 204-208.

Dunham KM. 1990. Fruit production by Acacia albida trees in Zambezi Riverine Woodlands. Journal of Tropical Ecology, 6(4): 445-457.

FAO: Handbook on Seeds of Dry-Zone Acacias. http://www.fao.org/docrep/006/ Q2190E/Q2190E10.htm

FAO. 1974a. Tree planting practices in african savannas. FAO Forestry Development Paper No. 19. FAO, Rome.

Faye MD, Weber JC, Abasse TA, Boureima M, Larwanou M, Bationo AB, Diallo BO, Sigué H, Dakouo J-M, Samaké O, Sonogo Diaité D. 2010. Farmers' preferences for tree functions and species in the West African Sahel. Forests, Trees and Livelihoods, 20: 1-15.

Larwanou M, Saadou M. 2011. The role of human interventions in tree dynamics and environmental rehabilitation in the Sahel zone of Niger. Journal of Arid Environments 75: 194-200.

Garrity DP, Akinnifesi FK, Ajayi OC, Sileshi G, Mowo J, Kalinganire A, Larwanou M, Bayala J. 2010. Evergreen agriculture: A robust approach to sustainable food security in Africa. Journal of Food Security, 2: 197-214.

Gérardin P, Neya B, Dumarçay S, Pétrisanns M, Serraj M, Huber F. 2004. Contribution of gums to natural durability of Prosopis 
africana heartwood. Holzforschung, 58: $39-44$.

Halliday J. 1984. Register of nodulation reports for leguminous trees and other arboreal genera with nitrogen fixing members. Nitrogen Fixing Tree Res. Rep., 2: 38-56.

IIED. 2003. Les conventions locales au Sahel: un outil de co-gouvernance en ressources naturelles. IIED 1.

Larwanou M, Saadou M. 2005. Biodiversity of ligneous species in semi-arid to arid zones of southwestern Niger according to anthropogenic and natural factors. Agriculture Ecosystems and Environment, 105: $1-2$ \& $267-271$.

Larwanou M. 1994. Potentials of Prosopis africana leaf litter for soil nutrient enhancement and crop development. M.Sc. thesis, Department of Forest Resources Management, University of Ibadan, Ibadan, p 95.

Larwanou M, Harouna NA, Abasse T, Niang A. 2007. Prosopis africana (Guill., Perrot et Rich.) Taub and Entada africana (Guill. et Perrot.) leaf litter decomposition and impact of biomass transfer on millet (Pennisetum glaucum (L.) R. Br.) growth and development on station in Niger; In: Advances in Integrated Soil Fertility Research in SubSaharan Africa: Challenges and Opportunities. Bationo A (eds), Springer; 815-825.

Larwanou M, Saadou M, Nonguierma A. 2005. Détermination du degré d'aridité bioclimatique de sept localités du Département de Tillabéri (sud-ouest du Niger): Classement en zones bioclimatiques. Sécheresse, 16: 1- 8.

Le Houerou HN. 1980. Le rôle des arbres et des arbustes dans les pâturages sahéliens. Le rôle des arbres au Sahel, pp.19-32, Colloque de Dakar, Nov. 1979, CRDI / IDRC, Otawa.

Lykke AM. 1998. Connaissances et préférences locales concernant les plantes ligneuses du Sahel au Burkina
Faso. SERIEN Occasional Paper 7: 71 83.

Nygård R, Elving B. 2000. Stem basic density and bark proportion of 45 woody species in young savanna coppice forests in Burkina Faso. Ann. For. Sci., 57: 143153.

Orwa C, Mutua A, Kindt R, Jamnadass R, Anthony S. 2009. Agroforestree Database:a tree reference and selection guide version 4.0

(http://www.worldagroforestry.org/sites/tr eedbs/treedatabases.asp)

Pasiecznik NM, Felker P, Harris PJC, Harsh LN, Cruz G, Tewari JC, Cadoret K, Maldonado LJ. 2001. The Prosopis juliflora - Prosopis pallida complex: a monograph. Henry Doubleday Research Association (HDRA), Coventry, p 172.

Paton D, Nunez J, Bao D, Munoz A. 2002. Forage biomass of 22 shrub species from Monfragu“ e Natural Park (SW Spain) assessed by log-log transformation models. J. Arid. Environ., 52: 223-231.

Roupsard O, Dauzat J, Nouvellon Y, Deveau A, Feintrenie L, Saint-Andre L, MialetSerra L, Braconnier S, Bonnefond J-M, Berbigier P, Epron D, Jourdan J, Navarro M, Bouillet J-P. 2008. Cross-validating Sun-shade and 3D models of light absorption by a tree-crop canopy. Agricultural and Forest Meteorology 14 (8): $549-564$.

Said S, Pellerin M, Guillon F, De' bias F, Fritz H. 2005. Assessment of forage availability in ecological studies. Eur. J. Wildl. Res., 51: 242-247.

Salis SM, Assis MA, Mattos PP, Piao ACS. 2006. Estimating the aboveground biomass and wood volume of savanna woodlands in Brazil's Pantanal wetlands based on allometric correlations. For. Ecol. Manage., 228: 61-68.

Sanon H, Kone O, Liehoun N, Poissonet E, Somda J, Morant M, de Wispelaere PG. 1995. Evaluation des potentialit'es pastorales du terroir de MENEGOU au Burkina Faso (Evaluation of grazing potential of the area of Menegou in 
Burkina Faso) Colloques et Séminaires ORSTOM, Paris, pp. 225-268.

Sanon HO, Kabore-Zoungrana C, Ledin I. 2007. Behaviour of goats, sheep and cattle and their selection of browse species on natural pasture in a Sahelian area. Small Ruminant Research, 67: 6474.

Savadogo P, Elfving B. 2007. Prediction models for estimating available fodder of two savanna tree species (Acacia dudgeoni and Balanites aegyptiaca) based on field and image analysis measures. African Journal of Range \& Forage Science, 24(2): 63 - 71.

Sotelo-Montes C, Agostinho da Silva D, Garcia R, Ines Bolzon de Muniz G, Weber JC. 2009. Calorific value of
Prosopis africana and Balanites aegyptiaca wood in the West African Sahel. Biomass Bioenergy (submitted)

Ter-Mikaelian MT, Korzukhin MD. 1997. Biomass equations for sixty-five North American tree species. For.Ecol. Manage., 97: 1-24.

Weber JC, Larwanou M, Tougiani AA, Kalinganire A. 2008. Growth and survival of Prosopis africana provenances related to rainfall gradients in the West African Sahel: Forest Ecology and Management, 256(4): 585592. 